\title{
Mild preoperative renal dysfunction as a predictor of long- term clinical outcome after coronary bypass surgery
}

Ruud M. A. van de Wal, MD, PharmD

Ben L. van Brussel, MD, PhD

Adriaan A. Voors, MD, $\mathrm{PhD}^{\mathrm{C}}$

Tom D. J. Smilde, MD ${ }^{\mathrm{C}}$

Johannes C. Kelder, MD

Henry A. van Swieten, MD, PhD, MSc ${ }^{d}$

Wiek H. van Gilst, $\mathrm{PhD}^{\mathrm{c}}$

Dirk Jan van Veldhuisen, $\mathrm{MD}, \mathrm{PhD}^{\mathrm{C}}$

H. W. Thijs Plokker, MD, PhD

From the Department of Cardiology, St Antonius Hospital, Nieuwegein, The Netherlands, ${ }^{a}$ Department of Cardiology, Bernhoven Hospital, Veghel, The Netherlands, ${ }^{\text {b }}$ Department of Cardiology, University Hospital Groningen, Thorax Center, Groningen, The Netherlands, ${ }^{c}$ and Department of Cardiothoracic Surgery, St Antonius Hospital, Nieuwegein, The Netherlands. ${ }^{d}$

Received for publication May 3, 2004; revisions received June 14, 2004; accepted for publication June 21, 2004

Address for reprints: Ruud M. A. van de Wal, MD, PharmD, Department of Cardiology, St Antonius Hospital, PO Box 2500, 3430 EM Nieuwegein, The Netherlands (Email: r.wal@antonius.net).

J Thorac Cardiovasc Surg 2005;129:330-5 $0022-5223 / \$ 30.00$

Copyright () 2005 by The American Association for Thoracic Surgery

doi:10.1016/j.jtcvs.2004.06.038
Background: Renal dysfunction is a prognostic marker in patients with cardiovascular disease. However, no long-term follow-up studies on the influence of mild renal dysfunction on mortality in patients undergoing coronary bypass grafting have been reported. Therefore, we aimed to identify the significance of preoperative (mild) renal dysfunction as a long-term predictor of clinical outcome after coronary bypass surgery.

Methods: In 358 patients who underwent isolated saphenous vein aorta-coronary artery bypass grafting, estimated glomerular filtration rates were calculated with the Cockroft-Gault equation (GFRc). Patients were categorized into 2 groups (group 1, GFRc $>71.1 \mathrm{~mL} \cdot \min ^{-1} \cdot 1.73 \mathrm{~m}^{-2}$; group 2 , GFRc $<71.1 \mathrm{~mL} \cdot \min ^{-1} \cdot 1.73 \mathrm{~m}^{-2}$ ). Multivariate Cox proportional hazard analyses were performed to determine the independent prognostic value of GFRc.

Results: During a median follow-up of 18.2 years, 233 patients $(65.1 \%)$ died. Patients who died had lower GFRc and were older. Multivariate analysis demonstrated that total mortality in patients with lower GFRc was significantly increased (lower GFRc group vs normal GFRc group: hazard ratio, 1.44; $P=.019$ ). Lower GFRc was also an independent predictor of cardiac mortality (hazard ratio, $1.51 ; P=.032$ ). No significant differences were observed between groups in the occurrence of myocardial infarction and the need for reintervention.

Conclusions: Our study demonstrates that after long-term follow-up, preoperative mild renal dysfunction is an independent predictor of long-term (cardiac) mortality in patients who undergo coronary artery bypass grafting.

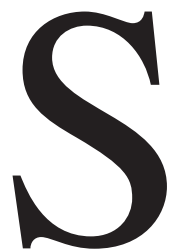

everal prognostic risk markers for mortality, reintervention, and the occurrence of cardiac events after coronary bypass surgery have been identified over the last 2 decades. We have already demonstrated that age and left ventricular function are continuous incremental risk factors for mortality. Left ventricular function and completeness of revascularization are independent predictors of cardiac death, and age and vessel disease are independent predictors of reintervention. Preoperative risk markers for cardiac events are hypertension, diabetes mellitus, hypertriglyceridemia, obesity, and smoking. ${ }^{1}$

Patients with chronic renal failure are known to have an increased risk of cardiovascular disease. ${ }^{2,3}$ In addition, outcome after coronary bypass surgery of 
Table 1. Baseline characteristics of both groups at time of surgery

\begin{tabular}{|c|c|c|c|}
\hline & $\begin{array}{c}\text { Group } 1(\mathrm{n}=215, \text { GFR }>70.1 \mathrm{~mL} \\
\left.\min ^{-1} \cdot 1.73 \mathrm{~m}^{-2}\right)\end{array}$ & $\begin{array}{c}\text { Group } 2(\mathrm{n}=143, \text { GFR }<70.1 \mathrm{~mL} . \\
\left.\min ^{-1} \cdot 1.73 \mathrm{~m}^{-2}\right)\end{array}$ & Significance (2-tailed) \\
\hline Mean age (y) & $49.7 \pm 6.5$ & $57.2 \pm 6.0$ & $<.001^{*}$ \\
\hline \multicolumn{4}{|l|}{ Sex } \\
\hline Male & $96.3 \%$ & $78.3 \%$ & $<.001 \dagger$ \\
\hline Female & $3.7 \%$ & $21.7 \%$ & \\
\hline BMI $\left(\mathrm{kg} / \mathrm{m}^{2}\right)$ & $24.1 \pm 1.5$ & $23.1 \pm 1.7$ & $<.001^{*}$ \\
\hline Serum creatinine $(\mathrm{mmol} / \mathrm{mL})$ & $97.2 \pm 11.1$ & $109.0 \pm 18.1$ & $<.001^{*}$ \\
\hline GFRc $\left(\mathrm{mL} \cdot \min ^{-1} \cdot 1.73 \mathrm{~m}^{-2}\right)$ & $85.1 \pm 11.0$ & $60.8 \pm 7.9$ & $<.001^{*}$ \\
\hline \multicolumn{4}{|l|}{ Diabetes mellitus } \\
\hline Yes & $98.6 \%$ & $96.5 \%$ & $.274 \dagger$ \\
\hline No & $1.4 \%$ & $3.5 \%$ & \\
\hline \multicolumn{4}{|l|}{ Smoking } \\
\hline Yes & $41.9 \%$ & $35.0 \%$ & \\
\hline No & $57.7 \%$ & $65.0 \%$ & $.186 \dagger$ \\
\hline Unknown & $0.4 \%$ & $0.0 \%$ & \\
\hline Cholesterol (mmol/L) & $7.61 \pm 1.42$ & $7.60 \pm 1.37$ & $.939 *$ \\
\hline Triglycerides (mmol/L) & $1.70 \pm 1.01$ & $1.70 \pm 1.30$ & $.968^{*}$ \\
\hline BP systolic (mm Hg) & $129 \pm 12$ & $132 \pm 12$ & $.007^{*}$ \\
\hline BP diastolic (mm Hg) & $85 \pm 11$ & $84 \pm 8$ & $.602^{*}$ \\
\hline Angina pectoris CCS class & & & $<.001 \dagger$ \\
\hline I & $3.3 \%$ & $0.7 \%$ & \\
\hline II & $45.6 \%$ & $30.8 \%$ & \\
\hline III & $37.7 \%$ & $44.1 \%$ & \\
\hline IV & $13.5 \%$ & $24.5 \%$ & \\
\hline \multicolumn{4}{|l|}{ Family history } \\
\hline Positive & $9.3 \%$ & $7.0 \%$ & \\
\hline Negative & $79.1 \%$ & $76.9 \%$ & $.561 \dagger$ \\
\hline Unknown & $11.6 \%$ & $16.1 \%$ & \\
\hline \multicolumn{4}{|l|}{ LV function (CASS-WMS score) } \\
\hline $5-7$ & $64.2 \%$ & $62.9 \%$ & \\
\hline 8-10 & $19.1 \%$ & $21.0 \%$ & $.904 \dagger$ \\
\hline$>10$ & $16.7 \%$ & $16.1 \%$ & \\
\hline One-vessel disease & $16.3 \%$ & $9.1 \%$ & \\
\hline Two-vessel-disease & $38.1 \%$ & $36.4 \%$ & $.034 \dagger$ \\
\hline Three-vessel-disease ( $>50 \%$ stenosis) & $45.6 \%$ & $54.5 \%$ & \\
\hline Extracorporeal circulation time (min) & $111 \pm 49$ & $115 \pm 49$ & $.695 \ddagger$ \\
\hline
\end{tabular}

Data are mean \pm SD. BMI, Body mass index; GFRc, glomerular filtration rate (GFR) according to the Cockroft-Gault equation; $B P$, blood pressure; CCS, Canadian Cardiovascular Society; CASS, Coronary Artery Surgery Study; WMS, wall motion score; LV, left ventricular.

*t Test.

$\dagger \chi^{2}$-test.

$\ddagger$ Mann-Whitney test.

patients with end-stage renal disease is poor, and in this group a 5-year survival of less than $50 \%$ has been observed. ${ }^{4}$ Anderson and colleagues ${ }^{5}$ demonstrated that patients with mild renal dysfunction are predisposed to adverse 30-day outcomes after coronary artery bypass surgery. However, no studies assessed the influence of mild preoperative kidney dysfunction on long-term outcome after coronary bypass surgery. Therefore, we aimed to identify the significance of renal function as a predictor of long-term clinical outcome after coronary bypass surgery.

\section{Methods Patients}

The clinical and angiographic definitions, as well as the surgical technique and patient characteristics, have been previously described in detail. ${ }^{6}$ Between April 1, 1976, and April 1, 1977, a series of 446 consecutive patients underwent isolated saphenous vein aorta-coronary bypass surgery in our hospital. Thirteen patients died within 30 days after surgery, and they were excluded from this analysis. Another 18 patients in whom the revascularization was combined with valve replacement surgery were also excluded. Of the remaining 415 patients, in 57 (13.7\%), the esti- 


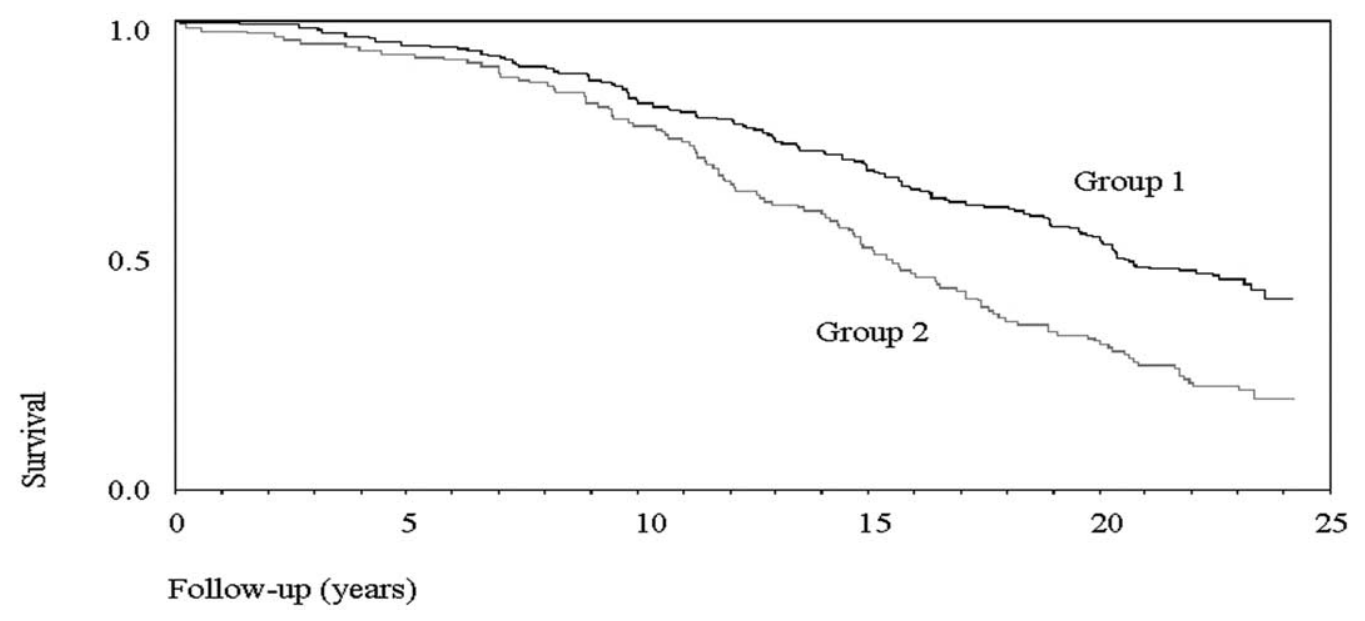

Figure 1. All-cause mortality after coronary artery bypass grafting in patients, based on their calculated creatinine clearance: group 1, cGFR greater than $70.1 \mathrm{~mL} \cdot \mathrm{min}^{-1} \cdot 1.73 \mathrm{~m}^{-2}$; group 2, cGFR less than $70.1 \mathrm{~mL} \cdot \mathrm{min}^{-1} \cdot 1.73 \mathrm{~m}^{-2}$.

mated glomerular filtration rates according to the Cockroft-Gault equation (GFRc) could not be calculated. This group was excluded as well. Therefore, this study population consisted of 358 patients. Several follow-up methods were used simultaneously to provide the most complete information possible. All patients were followed by using the anniversary method at our outpatient clinic or the outpatient clinic of referring cardiologists.

\section{Measurement of Serum Creatinine}

Serum creatinine was measured with standard techniques in the clinical chemistry laboratory of our institution from blood samples drawn the week before surgery. Serum creatinine then was used to calculate GFRc by using the Cockcroft-Gault equation [(140-age in years $) \times($ weight in $\mathrm{kg})] /(72 \times$ serum creatinine in $\mathrm{mg} / \mathrm{dL})$, multiplied by 0.85 in women. This equation is closely correlated with measured creatinine clearance (correlation coefficient, 0.83 ) and gives a more accurate assessment of renal function than serum creatinine alone. ${ }^{7}$

\section{Statistical Analysis}

In our analysis we categorized GFRc into quintiles, and the hazard ratios were calculated for the lower GFRc quintiles compared with the (reference) highest GFRc group. Univariate Cox proportional hazard analysis demonstrated that the lowest 2 quintiles and the highest 3 quintiles showed similar hazard ratios. Subsequently, the patients were categorized into 2 groups (group 1: GFRc $>71.1 \mathrm{~mL}$ $\cdot \min ^{-1} \cdot 1.73 \mathrm{~m}^{-2}$, quintiles 3, 4, and 5; group 2: GFRc $<71.1 \mathrm{~mL}$ $\cdot \min ^{-1} \cdot 1.73 \mathrm{~m}^{-2}$, quintiles 1 and 2). Age was dichotomized in a similar manner; this resulted in 2 groups with a cutoff point of 54.7 years.

To identify prognostic covariates that might have been responsible for a difference in survival time between groups, survival curves were estimated by the method described by Kaplan and Meier from the following variables: presence of left main vessel disease, left ventricular function, number of vessels involved, completeness of revascularization, preoperative diabetes mellitus, preoperative cholesterol, number of distal anas- tomoses, preoperative smoking behavior, and hypertension. The log-rank test was used to calculate the statistical significance of differences in survival curves between groups. All variables with a significance level of $P<.10$ in this univariate test were included in a multivariate model proposed by Cox. The clinical events studied were overall mortality, cardiac mortality, acute myocardial infarction, and reintervention. Cardiac death was defined as death from a documented cardiac cause or death from an unknown cause. End points were scored in an hierarchical manner. ${ }^{8}$ All statistical analyses were performed with SPSS software (version 11.0; SPSS Inc, Chicago, Ill), and all reported $P$ values are 2 sided.

\section{Results}

\section{Baseline Characteristics}

The mean age of the entire study population was 52.6 years (range, 20-74 years; SD, 7.35 years), and 10.9\% were women. The mean (SD) serum creatinine concentration in the 2 GFRc groups was $97.2 \mu \mathrm{mol} / \mathrm{L}(11.1 \mu \mathrm{mol} / \mathrm{L})$ and $109.0 \mu \mathrm{mol} / \mathrm{L}(18.1 \mu \mathrm{mol} / \mathrm{L})$, respectively. Only 3 patients had a GFRc $<40 \mathrm{~mL} \cdot \mathrm{min}^{-1} \cdot 1.73 \mathrm{~m}^{-2}$ (minimum, $32.1 \mathrm{~mL}$ $\cdot \min ^{-1} \cdot 1.73 \mathrm{~m}^{-2}$ ). The mean GFRc of both groups was within 2 SD of normal GFR values in the general population. ${ }^{9}$ Other baseline clinical characteristics are shown in Table 1. Thirty-day operative mortality for the study population was $2.9 \%$. Only 1 patient was lost to follow-up. The median duration of follow-up was 18.2 years.

\section{All-Cause Mortality}

Cumulative survival of the 2 groups is shown in Figure 1. In the high-GFRc group, 120 patients (45.2\%) died, whereas in the low-GFRc group, 113 patients $(79.0 \%)$ died. The variables with a significance level of $P<.10$ in the univariate tests were age, left ventricular function, preoperative diabetes mellitus, number of anastomoses, 
Table 2. Univariate hazard ratios (95\% confidence intervals) for total mortality and cardiac mortality of statistically significant and other predictors for either total mortality or cardiac mortality

\begin{tabular}{|c|c|c|c|c|}
\hline \multirow[b]{3}{*}{ Variable } & \multicolumn{4}{|c|}{ From $30 \mathrm{~d}$ after surgery to $\mathbf{1 8 . 2} \mathrm{y}$ after surgery } \\
\hline & \multicolumn{2}{|c|}{ Total mortality } & \multicolumn{2}{|c|}{ Cardiac mortality } \\
\hline & HR $(95 \%$ Cl) & $P$ value & HR $(95 \%$ CI) & $P$ value \\
\hline Age $(>54.7$ y) & $2.08(1.60-2.69)$ & $<.001$ & $1.73(1.26-2.38)$ & .001 \\
\hline Completeness of revascularization & $1.35(1.04-1.75)$ & .026 & $1.73(1.26-2.37)$ & .001 \\
\hline Diabetes mellitus & $2.29(1.08-4.88)$ & .031 & $2.00(0.74-554)$ & .169 \\
\hline Body mass index & $1.00(0.92-1.08)$ & .928 & $0.99(0.90-1.10)$ & .895 \\
\hline \multicolumn{5}{|l|}{ No. of diseased vessels } \\
\hline Two-vessel disease & $1.23(0.79-1.91)$ & .366 & $2.04(1.07-3.89)$ & .031 \\
\hline Three-vessel disease & $1.78(1.16-2.71)$ & .008 & $3.03(1.62-5.68)$ & .001 \\
\hline LMCA involved & $1.63(1.13-2.35)$ & .009 & $1.66(1.07-2.59)$ & .024 \\
\hline \multicolumn{5}{|l|}{ LV function (CASS-WMS) } \\
\hline$<8$ vs. $8-10$ & $2.02(1.37-3.00)$ & $<.001$ & $1.78(1.29-2.45)$ & $<.001$ \\
\hline$<8$ vs. $>10$ & $3.59(2.45-5.25)$ & $<.001$ & $2.63(1.90-3.65)$ & $<.001$ \\
\hline $\operatorname{Sex}(M / F)$ & $1.23(0.83-1.82)$ & .311 & $1.25(0.77-2.02)$ & .365 \\
\hline Smoking & $1.17(0.90-1.52)$ & .235 & $1.10(0.79-1.51)$ & .581 \\
\hline Cholesterol & $0.97(0.88-1.08)$ & .581 & $1.00(0.88-1.13)$ & .978 \\
\hline Triglycerides & $1.05(0.93-1.18)$ & .422 & $1.09(0.95-1.24)$ & .245 \\
\hline No. of anastomoses & $1.13(1.03-1.24)$ & .013 & $1.20(1.07-1.34)$ & .001 \\
\hline GFR $\left(\leq 70.1 \mathrm{~mL} \cdot \mathrm{min}^{-1} \cdot 1.73 \mathrm{~m}^{-2}\right)$ & $1.82(1.41-2.36)$ & $<.001$ & $1.74(1.27-2.39)$ & .001 \\
\hline
\end{tabular}

$C l$, Confidence intervals; $H R$, hazard ratio; $L V$, left ventricular; $L M C A$, left main coronary artery; CASS, Coronary Artery Surgery Study; WMS, wall motion score; GFR, glomerular filtration rate.

Table 3. Multivariate hazard ratios (95\% confidence intervalss) for total mortality and cardiac mortality of statistically significant and other predictors for either total mortality or cardiac mortality

\begin{tabular}{|c|c|c|c|c|}
\hline \multirow[b]{3}{*}{ Variable } & \multicolumn{4}{|c|}{ From $30 \mathrm{~d}$ after surgery to $\mathbf{1 8 . 2} \mathrm{y}$ after surgery } \\
\hline & \multicolumn{2}{|c|}{ Total mortality } & \multicolumn{2}{|c|}{ Cardiac mortality } \\
\hline & HR $(95 \%$ CI) & $P$ value & HR $(95 \%$ CI) & $P$ value \\
\hline Age $(>54.7$ y) & $1.72(1.27-2.33)$ & $<.001$ & $1.43(0.99-2.08)$ & .058 \\
\hline Completeness of revascularization & $1.16(0.88-1.53)$ & .298 & $1.40(1.00-1.95)$ & .050 \\
\hline Diabetes mellitus & $2.02(0.93-4.41)$ & .077 & - & \\
\hline \multicolumn{5}{|l|}{ No. of diseased vessels } \\
\hline Two-vessel disease & $0.97(0.59-1.60)$ & .895 & $1.43(0.71-2.90)$ & .316 \\
\hline Three-vessel disease & $1.03(0.58-1.84)$ & .914 & $1.50(0.69-3.28)$ & .308 \\
\hline LMCA involved & $1.57(1.08-2.29)$ & .020 & $1.53(0.97-2.42)$ & .070 \\
\hline \multicolumn{5}{|l|}{ LV function (CASS-WMS) } \\
\hline$<8$ vs. $8-10$ & $1.68(1.22-2.33)$ & .002 & $1.43(0.71-2.90)$ & .001 \\
\hline$<8$ vs. $>10$ & $2.52(1.80-3.53)$ & $<.001$ & $3.10(2.10-4.57)$ & $<.001$ \\
\hline No. of anastomoses & $1.06(0.93-1.21)$ & .366 & $1.09(0.94-1.27)$ & .275 \\
\hline GFR $\left(\leq 70.1 \mathrm{~mL} \cdot \min ^{-1} \cdot 1.73 \mathrm{~m}^{-2}\right)$ & $1.44(1.06-1.96)$ & .019 & $1.51(1.04-2.19)$ & .032 \\
\hline
\end{tabular}

$\overline{C l}$, Confidence intervals; $H R$, hazard ratio; $L M C A$, left main coronary artery; $L V$, left ventricular; CASS, Coronary Artery Surgery Study; WMS, wall motion score; GFR, glomerular filtration rate.

number of vessels involved, left main coronary artery disease, completeness of revascularization, and categorized preoperative GFRc (Table 2). These values were included in a multivariate analysis model. Multivariate analysis identified 3 preoperative risk factors that were related to long-term mortality: age, left ventricular function, and preoperative renal function (Table 3). Patients in group 2 had a significantly increased risk of mortality during follow-up (group 2 vs group 1: hazard ratio, 1.44; 95\% CI 1.06-1.96; $P=.019$ ).

\section{Cardiac Mortality}

Cumulative survival of the 2 groups is shown in Figure 2. In the high-GFRc group, 83 patients (38.6\%) died of cardiac 


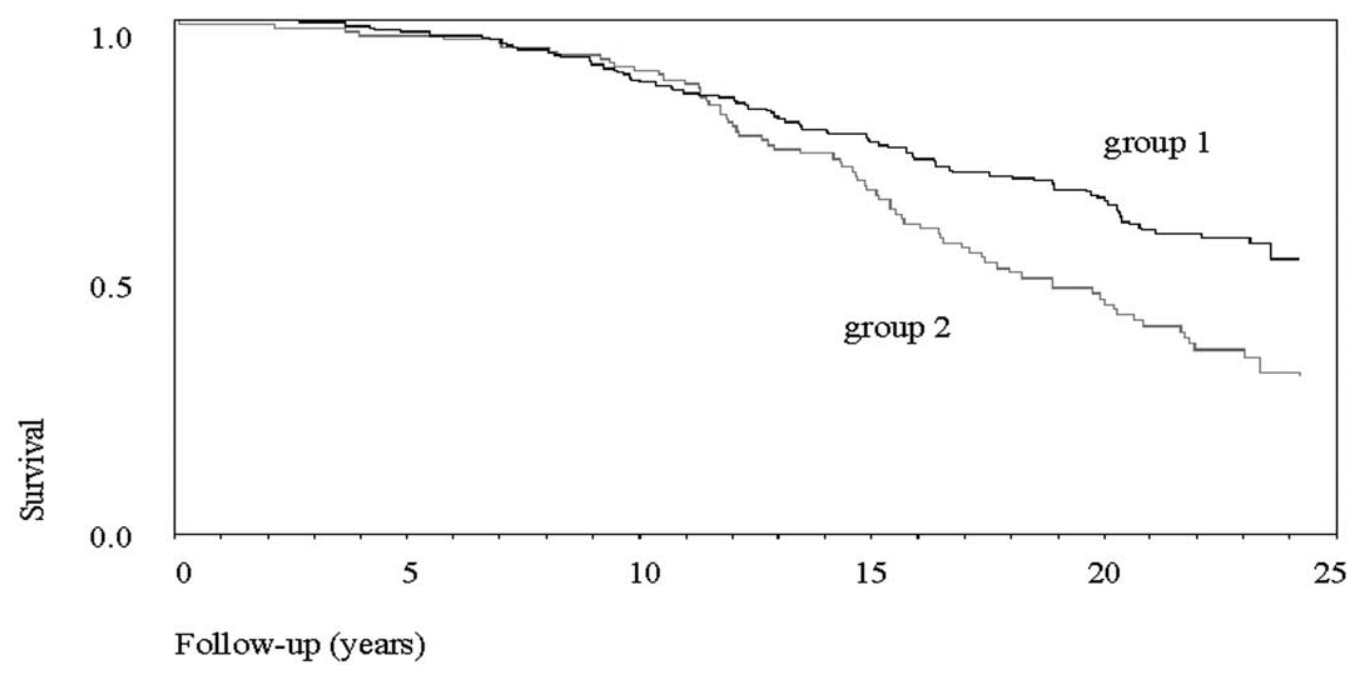

Figure 2. Cardiac mortality after coronary artery bypass grafting in patients, based on their calculated creatinine clearance: group 1, cGFR greater than $70.1 \mathrm{~mL} \cdot \mathrm{min}^{-1} \cdot 1.73 \mathrm{~m}^{-2}$; group 2, cGFR less than $70.1 \mathrm{~mL} \cdot \mathrm{min}^{-1} \cdot 1.73 \mathrm{~m}^{-2}$.

cause, whereas in the other group, 74 patients (51.7\%) died of cardiac causes. The variables with a significance level of $P<.10$ in the univariate tests were age, left ventricular function, number of anastomoses, number of diseased vessels, left main coronary artery disease, completeness of revascularization, and preoperative GFRc (Table 2). If only cardiac death was taken into account, categorized preoperative kidney function was still a significant risk factor (group 2 vs group 1: hazard ratio, 1.51; 95\% CI 1.04-2.19; $P=.032$ ). The 2 most powerful predictors of cardiac mortality after multivariate analysis were left ventricular function and preoperative kidney function (Table 3).

\section{Myocardial Infarction and Reintervention}

No significant differences were found between groups in the occurrence of (re)myocardial infarction (group 2 vs group 1 : hazard ratio, $1.29 ; P=.219$ ) or in the reintervention rate (group 2 vs group 1: hazard ratio, 1.38; $P=.198$ ). These data are not shown.

\section{Discussion}

In this long-term follow-up study, we demonstrated that mild preoperative renal dysfunction is an independent predictor of long-term mortality. Ischemic heart disease is the most common cause of death in patients with chronic kidney disease, ${ }^{10,11}$ and renal dysfunction has now been generally recognized as a risk marker in a wide variety of patients with cardiovascular disease. ${ }^{12}$ It has been well established that patients with severe chronic renal failure have a high risk for adverse outcome after coronary bypass surgery. ${ }^{5,13,14}$ Several studies showed that patients with mild renal dysfunction have an increased risk of dying within 30 days after coronary surgery. ${ }^{5,13,15}$ Patients with decreased renal function (serum creatinine $\geq 2.0 \mathrm{mg} / \mathrm{dL}$ ) carry significant operative risks, require prolonged hospital stays, and have a higher risk of dying within 3 years after coronary surgery. ${ }^{15}$ Nakayama and colleagues ${ }^{13}$ demonstrated that in a group of patients with a preoperative serum creatinine level of $1.5 \mathrm{mg} / \mathrm{dL}$ or greater $(\geq 133 \mu \mathrm{mol} / \mathrm{L})$, the 10 -year actuarial survival was significantly lower than in a group of patients with normal serum creatinine levels $(<1.0$ $\mathrm{mg} / \mathrm{dL} ;<88 \mu \mathrm{mol} / \mathrm{L}$ ). Most patients in our population had a milder preoperative renal dysfunction than described in these studies, yet this parameter was still an independent predictor for mortality. It is interesting to note that KaplanMeier analysis clearly demonstrated that differences between GFR groups occurred only after approximately 10 years of follow-up. Possibly, this mirrors an accelerated rate of atherosclerosis, although in our population no difference in myocardial infarction was observed between groups.

Several explanations have been proposed for the association between renal dysfunction, cardiovascular disease, and mortality. ${ }^{3,16,17}$ First, renal dysfunction is often associated with the presence of other cardiovascular risk factors, such as hypertension and diabetes. In these cases, renal dysfunction and cardiovascular morbidity would both be the results of end-organ damage. However, the effect of renal function on mortality in this study was independent of other known cardiovascular risk factors. Second, renal dysfunction might be the direct effect of cardiac dysfunction. In patients with a reduction of cardiac output, there is a decline in renal perfusion and an activation of compensatory mechanisms, which leads to renal function impairment. ${ }^{18,19}$ In these cases, renal dysfunction is a reflection of the cardiac function and may therefore be used as a risk marker for 
cardiovascular morbidity and mortality. ${ }^{20}$ In our patients, this mechanism probably does not play a role, because only a few patients had a significantly reduced left ventricular systolic function. Finally, renal dysfunction also has a negative effect on lipids, oxidative stress, homocysteine, and fibrinogen; this could lead to endothelial dysfunction. ${ }^{21}$ However, the question of whether endothelial dysfunction is the connecting bond between cardiovascular risk factors and renal dysfunction remains to be answered.

Patients receiving venous coronary bypass grafts often need reintervention and also have a worse prognosis compared with patients receiving arterial bypass grafts. ${ }^{22}$ Angiographic and necropsy studies have found evidence of accelerated atherosclerosis in saphenous vein conduits, possibly as a result of chronic endothelial activation. ${ }^{23}$ Nowadays arterial grafts are preferred to venous grafts, yet venous conduits continue to be used in a large proportion of coronary artery bypass grafting patients. Consequently, it is important to identify all patients at risk.

\section{Limitations}

This was a post hoc analysis of prospective data. Therefore, the results and conclusions are subject to the limitations inherent to such analysis. However, the principal variables of interest-serum creatinine and death-are objective measures. The Cockroft-Gault equation is an estimate of the GFR and might lead to an overestimation of these parameters. Because this estimation was used for all patients and because GFR was an independent predictor of poor outcome, this should not affect our conclusions. Furthermore, GFR is only a surrogate marker for kidney function. In patients with an impaired GFR, no conclusions can be drawn concerning the etiology of the problem. Our study is also limited by a lack of data on the progression of renal impairment during follow-up. Finally, the study is limited by the number of (mainly white) patients participating and the fact that they were all in the same hospital.

\section{Conclusion}

This study demonstrates that preoperative mild renal dysfunction is an important independent risk marker of longterm survival in patients after coronary bypass surgery.

\section{References}

1. van Brussel BL, Voors AA, Ernst JM, Knaepen PJ, Plokker HW. Venous coronary artery bypass surgery: a more than 20-year follow-up study. Eur Heart J. 2003;24:927-36.

2. Baigent C, Burbury K, Wheeler D. Premature cardiovascular disease in chronic renal failure. Lancet. 2000;356:147-52.

3. Jungers P, Massy ZA, Khoa TN, Fumeron C, Labrunie M, Lacour B, et al. Incidence and risk factors of atherosclerotic cardiovascular accidents in predialysis chronic renal failure patients: a prospective study. Nephrol Dial Transplant. 1997;12:2597-602.
4. Dacey LJ, Liu JY, Braxton JH, Weintraub RM, DeSimone J, Charlesworth DC, et al. Long-term survival of dialysis patients after coronary bypass grafting. Ann Thorac Surg. 2002;74:458-62.

5. Anderson RJ, O'brien M, MaWhinney S, VillaNueva CB, Moritz TE, Sethi GK, et al. Renal failure predisposes patients to adverse outcome after coronary artery bypass surgery. VA Cooperative Study \#5. Kidney Int. 1999;55:1057-62.

6. van Brussel BL, Plokker HW, Ernst SM, Ernst NM, Knaepen PJ, Koomen EM, et al. Venous coronary artery bypass surgery. A 15-year follow-up study. Circulation. 1993;88:II87-92.

7. Wang F, Dupuis JY, Nathan H, Williams K. An analysis of the association between preoperative renal dysfunction and outcome in cardiac surgery: estimated creatinine clearance or plasma creatinine level as measures of renal function. Chest. 2003;124:1852-62.

8. Voors AA, van Brussel BL, Plokker HW, Ernst SM, Ernst NM, Koomen EM, et al. Smoking and cardiac events after venous coronary bypass surgery. A 15-year follow-up study. Circulation. 1996;93:42-7.

9. K/DOQI clinical practice guidelines for chronic kidney disease. evaluation, classification, and stratification. Am J Kidney Dis. 2002;39:S1266.

10. Herzog CA, Ma JZ, Collins AJ. Poor long-term survival after acute myocardial infarction among patients on long-term dialysis. $N$ Engl J Med. 1998;339:799-805.

11. Walsh CR, O’Donnell CJ, Camargo CA Jr, Giugliano RP, Lloyd-Jones DM. Elevated serum creatinine is associated with 1-year mortality after acute myocardial infarction. Am Heart J. 2002;144:1003-11.

12. Hillege HL, van Gilst WH, van Veldhuisen DJ, Navis G, Grobbee DE, de Graeff PA, et al. Accelerated decline and prognostic impact of renal function after myocardial infarction and the benefits of ACE inhibition: the CATS randomized trial. Eur Heart J. 2003;24:412-20.

13. Nakayama Y, Sakata R, Ura M, Itoh T. Long-term results of coronary artery bypass grafting in patients with renal insufficiency. Ann Thorac Surg. 2003;75:496-500.

14. Mangano CM, Diamondstone LS, Ramsay JG, Aggarwal A, Herskowitz A, Mangano DT. Renal dysfunction after myocardial revascularization: risk factors, adverse outcomes, and hospital resource utilization. The Multicenter Study of Perioperative Ischemia Research Group. Ann Intern Med. 1998;128:194-203.

15. Hirose H, Amano A, Takahashi A, Nagano N. Coronary artery bypass grafting for patients with non-dialysis-dependent renal dysfunction (serum creatinine $>$ or $=2.0 \mathrm{mg} / \mathrm{dl}$ ). Eur J Cardiothorac Surg. 2001; 20:565-72.

16. Fried LF, Shlipak MG, Crump C, Bleyer AJ, Gottdiener JS, Kronmal RA, et al. Renal insufficiency as a predictor of cardiovascular outcomes and mortality in elderly individuals. J Am Coll Cardiol. 2003; 41:1364-72.

17. Ritz E, Dikow R, Ruilope LM. Renal dysfunction as a cardiovascular risk factor. Curr Hypertens Rep. 2002;4:365-8.

18. Ljungman S, Laragh JH, Cody RJ. Role of the kidney in congestive heart failure. Relationship of cardiac index to kidney function Drugs. 1990;39(suppl 4):10-21.

19. Magri P, Rao MA, Cangianiello S, Bellizzi V, Russo R, Mele AF, et al. Early impairment of renal hemodynamic reserve in patients with asymptomatic heart failure is restored by angiotensin II antagonism. Circulation. 1998;98:2849-54.

20. Hillege HL, Girbes AR, de Kam PJ, Boomsma F, de Zeeuw D, Charlesworth A, et al. Renal function, neurohormonal activation, and survival in patients with chronic heart failure. Circulation. 2000;102: 203-10.

21. Best PJ, Lennon R, Ting HH, Bell MR, Rihal CS, Holmes DR, et al. The impact of renal insufficiency on clinical outcomes in patients undergoing percutaneous coronary interventions. J Am Coll Cardiol. 2002;39:1113-9.

22. Loop FD, Lytle BW, Cosgrove DM, Stewart RW, Goormastic M, Williams GW, et al. Influence of the internal-mammary-artery graft on 10-year survival and other cardiac events. N Engl J Med. 1986;314:1-6.

23. Motwani JG, Topol EJ. Aortocoronary saphenous vein graft disease: pathogenesis, predisposition, and prevention. Circulation. 1998;97: 916-31. 